\title{
Effect of porcine somatotropin on metabolism, testicular size and sperm characteristics in young boars
}

\author{
[Efeito da somatotrofina suína sobre o metabolismo, o tamanho testicular e a qualidade \\ espermática de cachaços jovens] \\ V.R. Rabassa ${ }^{1}$, J.O. Feijó ${ }^{1}$, D. Perazzoli ${ }^{1}$, C.M. Pereira ${ }^{2}$, A.L.P. Schild ${ }^{1}$, T. Lucia Júnior ${ }^{1}$, \\ C.D. Corcini ${ }^{1}$, E. Schmitt ${ }^{1}$, A. Schneider ${ }^{1}$, F.A.B.D. Pino ${ }^{1}$, I. Bianchi ${ }^{3}$, M.N. Corrêa ${ }^{1}$ \\ ${ }^{1}$ Universidade Federal de Pelotas - Pelotas, RS \\ ${ }^{2}$ Centro Universitário Ritter dos Reis - UniRitter - Porto Alegre, RS \\ ${ }^{3}$ Instituto Federal Catarinense - IFC - Campus Araquari, SC
}

\begin{abstract}
The aim of this study was to evaluate the effect of pST injections on metabolism, testicular size, and sperm characteristics in young boars. Sixty 22-day old piglets were divided into two groups: pST $(n=30)$ and Control $(\mathrm{n}=30)$. The pST group was submitted to pST injections $(90 \mu \mathrm{g} / \mathrm{kg}$ body weight $)$ every three days up to 330 days of age. Blood collections were performed weekly. Testicular weight was measures at 22, 82, 142, 202 and 365 days of age. Libido and fresh semen characteristics were evaluated between 150 and 210 days of age. Semen characteristics were also evaluated during a $72 \mathrm{~h}$ storage period $\left(15^{\circ} \mathrm{C}\right)$. Testosterone, albumin, and phosphorus blood concentrations were higher in the pST group $(\mathrm{P}<0.05)$. The pST group had a higher IGF-I concentration in seminal plasma $(\mathrm{P}=0.05)$ and higher testicular weight $(\mathrm{P}<0.001)$ compared to the Control group. The pST group had higher ejaculate volume $(\mathrm{P}<0.001)$, total sperm count $(\mathrm{P}=0.047)$ and number of inseminating doses/ejaculate $(\mathrm{P}=0.047)$. During the $72 \mathrm{~h}$ storage period, the pST group had a lower number of morphological alterations $(\mathrm{P}<0.001)$ compared to the Control group. In sum, pST injection in young boars increased testosterone concentration, testicular size, and sperm quality.
\end{abstract}

Keywords: swine, growth hormone, pST, testicle, semen

\section{RESUMO}

O objetivo deste estudo foi determinar o efeito da administração de pST sobre o metabolismo, o tamanho testicular e a qualidade espermática de cachaços jovens. Foram usados leitões com 22 dias de idade, divididos em dois grupos: $\mathrm{pST}(\mathrm{n}=30)$ e controle $(n=30)$. O grupo pST foi submetido a injeções de pST $(90 \mu \mathrm{g} / \mathrm{kg}$ de peso vivo) a cada três dias até 330 dias de idade. Peso testicular foi avaliado aos 22, 82, 142, 202 e 365 dias de idade. Libido e qualidade do sêmen fresco foram avaliados entre 150 e 210 dias de idade. Qualidade espermática foi avaliada durante refrigeração $\left(15^{\circ} \mathrm{C}\right)$ por um período de 72 horas. Concentrações sanguíneas de testosterona, albumina e fósforo foram maiores no grupo pST $(P<0,05)$. O grupo pST apresentou maior concentração de IGF-I no plasma seminal $(P=0,05)$ e maior peso testicular, quando comparado ao grupo controle $(P<0,001)$. O grupo pST apresentou maior volume espermático $(P<0,001)$, concentração espermática $(P=0,047)$ e número de doses espermáticas por ejaculado $(P=0,047)$. Durante o período de 72 horas de refrigeração, o grupo $\mathrm{pST}$ teve menor número de patologias espermáticas $(P<0,001)$. Assim, conclui-se que a administração de pST aumenta a concentração sanguínea de testosterona, o tamanho testicular e a qualidade espermática de cachaços jovens.

Palavras-chave: suíno, hormônio do crescimento, pST, testículo, sêmen

\section{INTRODUCTION}

The sexual maturity of male pigs is influenced by different factors, such as breed, nutrition and environmental effects (Kumaresan et al., 2011), and therefore can vary greatly between

Recebido em 30 de setembro de 2016

Aceito em 18 de abril de 2017

E-mail: vivianerabassa@gmail.com individuals. The gonadotropin-releasing hormone (GnRH) regulates the levels of luteinizing hormone (LH) and follicle-stimulating hormone (FSH) and, as a consequence, testosterone production and Sertoli cell activity, respectively, regulating age at sexual maturity (Finnerty et al., 1998). The increase of testosterone production 
plays a crucial role in the establishment of puberty and the onset of sperm production, as its serum levels are positively correlated to testicular development, puberty, sexual maturity and sperm production (Park and Yi, 2002). Metabolic hormones, such as growth hormone (GH), may also influence sexual maturity. Exogenous GH supplementation is positively associated with improved testicular development, gametogenesis and steroidogenesis, and $\mathrm{GH}$ replacement therapy can accelerate puberty in young men with endogenous $\mathrm{GH}$ deficiency (Kamp et al., 2002). However, the specific effects of GH supplementation in animals and humans with normal reproductive function are still unclear. Some studies indicate improvement of sperm quality in horses (Storer et al., 2005) and bulls receiving exogenous GH (Hafez et al., 2005; Vieira et al., 2010); while others have demonstrated adverse effects on testicular development in dogs (Sjogren et al., 1998).

The effects of GH are mostly mediated by hepatic produced insulin-like growth factor-I (IGF-I), which is stimulated by GH (Sirotkin, 2005). IGF-I is a mitotic factor and can improve testicular development (Swanlund et al., 1995). IGF-I can also stimulate the proliferation of Sertoli cells and the development of seminiferous tubules in prepubertal males (Swanlund et al., 1995). Besides, reduced IGF-I serum concentration is associated with a delay in testosterone production prior to puberty in undernourished steers (Brito et al., 2007). IGF-I has also been detected in seminal plasma (Henricks et al., 1998; Selvaraju et al., 2009). Therefore, the effect of local IGF-I production should not be disregarded, since seminal plasma IGF-I is positively associated to sperm motility (Henricks et al., 1998). The administration of exogenous $\mathrm{GH}$ can also increase circulating concentrations of $\mathrm{LH}$ as well as the expression of its receptors in target tissues (Chatelain et al., 1991; Sirotkin, 2005). Increased LH secretion in the postnatal period is related to maturation and differentiation of Leydig cells and an increased testosterone production (Bagu et al., 2006). Although it is known that $\mathrm{GH}$ is positively associated with circulating concentrations of gonadotropins in rats (Sirotkin, 2005), this is not true for ruminants (Folch et al., 2001), and is unknown for swine. Therefore, it can be hypothesized that the combined effects of $\mathrm{GH}$ on LH and IGF-I secretion can increase testicular cell proliferation and steroidogenesis, thus improving sperm production and quality.

Based on this, the aim of this study was to determine the effect of pST injections in young pigs on blood metabolites, testicular size, sperm characteristics and biochemical constituents of the seminal plasma.

\section{MATERIALS AND METHODS}

This research was approved by the Ethics Committee on Animal Experimentation of the Federal University of Pelotas (CEEA 6574).

Sixty 22-day old piglets (Landrace x Large White) were randomly assigned to one of two groups: pST $(n=30)$ and Control $(n=30)$. The pST group received pST injections $(90 \mu \mathrm{g} / \mathrm{kg}$ of body weight (BW) i.m.) (Reporcin, OzBioPharm Pty Ltd, Knoxfield, Vic., Australia) every three days (Rabassa et al., 2014) up to 330 days of age. The Control group received placebo treatment (sodium chloride $0.9 \%$, i.m.) at the same frequency. The pigs were weighed weekly up to 365 days of age.

Blood collections were performed weekly by venipuncture of the jugular during the period of hormonal treatments and continued for five weeks after the last injection (365 days of age). Serum was harvested after centrifugation at $3000 \mathrm{~g}$ for $15 \mathrm{~min}$ and frozen at $-80^{\circ} \mathrm{C}$ for later analysis. Testosterone (Testosterone, NovaTec Immundiagnostica GmbH, Germany) and IGF-I (Uscn Sciences Co., Ltd., China) concentrations were evaluated by a commercial ELISA kit according to manufacturer's instructions, and both had intra- and inter-assay coefficients of variation $(\mathrm{CV})$ below $10 \%$. IGF-I levels were measured after acid-ethanol extraction to remove IGF binding proteins and measure total IGF-I.

Glucose, cholesterol, urea, albumin, phosphorous, aspartate amino transferase (AST), gamma glutaryltransferase (GGT) (Labtest Diagnóstica S.A., Brazil) and non-esterified fatty acids (NEFA - Wako Diagnostics, USA) serum concentrations were determined by colorimetric methods following manufacturer's instructions (Labtest Diagnóstica S.A., Brazil). CV was below $10 \%$ for all analyses.

At 22, 82, 142, 202 and 365 days of age, six animals from each group were submitted to 
orchiectomy surgery. Animals were sedated using $40 \%$ azaperone (Stresnil, Janssen Animal Healty, Belgium; i.m. $4 \mathrm{~mL} / 20 \mathrm{~kg}$ BW). The scrotum was locally anesthetized with $2 \%$ lidocaine (Anestésico L Pearson - Laboratório Pearson Ltda, Brazil) and two scrotal incisions were performed for testicle removal. The left testicle was separated from the epididymis and weighed.

Libido evaluation began after the boars had become used to the semen collection management, which ranged from 150 days up to 210 days of age. Boars were separately taken to a semen collection room equipped with an artificial sow three times a week. Individual training sessions lasted a maximum of $10 \mathrm{~min}$. During each session, boar libido was classified on a $1-4$ score scale, similar to that described by Kozink et al. (2002) where: 1 - boars showed no interest in the artificial sow; 2 - slight interest in the artificial sow but did not attempt to mount; 3 - mounted the artificial sow but did not allow semen collection; 4 - mounted the artificial sow and allowed semen collection. Duration of interest for the artificial sow was recorded in seconds. The number of attempts needed until first mount and first ejaculation were also evaluated.

Whole ejaculates were collected using the gloved-hand technique. Semen (without the gelatinous fraction) was evaluated three times a week as to appearance (samples with urine or blood were discarded), volume $(\mathrm{mL})$, motility $(\%)$ and vigor (0-5 score, higher values indicates more vigorous sperm) in the period between 150 and 210 days of age (during semen collection training).

After 210 days of age, whole ejaculates (without the gelatinous fraction) were collected weekly using the gloved-hand technique up to 35 days after the last pST treatment (365 days of age) for all boars in the study. After an initial appearance evaluation (samples with urine or blood were discarded), volume (mL), $\mathrm{pH}$, motility (\%) and vigor (0-5 score) were evaluated. The semen was diluted 1:1 with BTS extender (Beltsville Thawing Solution, BTS; Minitüb, Tiefenbach, Germany). The sperm concentration was counted in a Neubauer chamber $\left(\times 10^{6} / \mathrm{mL}\right)$, total count (x10\% /ejaculate) and the semen volume needed to obtain a dose with three billion spermatozoa. The ejaculate was brought to a final volume of $100 \mathrm{~mL}$ with addition of BTS. Semen doses were then maintained at room temperature in low light condition for 2 hours and stored at $15-18^{\circ} \mathrm{C}$ in a refrigerator for 72 hours.

Semen doses were evaluated every 24 hours ( 0 , 24, 48 and 72 hours) for motility, vigor and morphology (\%) during the $72 \mathrm{~h}$ storage period. For this assessment, a mixture of semen and $3 \%$ formol-citrate was made and evaluated under a phase contrast microscope (1000x). Tail abnormalities, isolated head, presence of proximal and distal cytoplasmic drops and total number of morphologically normal cells were calculated. Plasma and acrosome membrane integrity and mitochondrial function were also evaluated by fluorescents probes. Sperm membrane integrity was evaluated using carboxyfluoresceindiacetate (CFDA) and propidium iodide (PI) markers as described by Harrison and Vickers (1990). To evaluate acrosomal integrity, Lectin from Arachishypogaea FITC Conjugate and PI were used as fluorescence markers. Mitochondrial function was evaluated by using the method described by Fraser et al. (2002) with PI and rhodamine 123 (R123). Evaluations were performed under an epifluorescent microscope (Olympus BX 51, America Inc., Sapporo, Japan) at $400 \mathrm{x}$ magnification (524 $\mathrm{nm}$ filter wave length). Two hundred sperms were counted on each slide and the membranes (acrosomal and plasmatic) were classified as intact or damaged. All evaluations were performed by the same technician.

Ejaculate aliquots were separated immediately after collection and centrifuged at $3000 \mathrm{x}$ g for $15 \mathrm{~min}$ to separate the seminal plasma, which was frozen at $-80^{\circ} \mathrm{C}$ for analysis. IGF-I concentration was evaluated by a commercial ELISA kit (Uscn Sciences Co., Ltd., China), after acid-ethanol extraction to remove IGF binding proteins as previously described for serum. Cholesterol, total protein (Labtest Diagnóstica S.A., Brazil) and fructose concentrations were evaluated by colorimetric methods. For fructose evaluation, $500 \mu \mathrm{L}$ seminal plasma was diluted in $950 \mu \mathrm{L}$ distilled water. The sample was deproteinized by adding $2 \%$ zinc sulphate and $0.4 \%$ sodium hydroxide and centrifuged at $2000 \mathrm{~g}$ for $5 \mathrm{~min}$; the supernatant was removed, $1 \mathrm{~mL}$ of $0.1 \%$ resorcinol and $3 \mathrm{~mL}$ of $30 \% \mathrm{HCl}$ were added and 
the solution was heated for $20 \mathrm{~min}$ at $85^{\circ} \mathrm{C}$. The final solution was read at $450 \mathrm{~nm}$ in a spectrophotometer. CV was below $10 \%$ for all analyses.

Statistical analysis was performed using Statistical Analysis System 9 software (SAS Institute Inc. Cary, NC, USA). Analysis of variance for repeated measures was used to examine the effect of pST injections (effect of treatment, collection and treatment $\mathrm{x}$ collection interaction) on testicular size, metabolic profile (testosterone, IGF-I, glucose, cholesterol, urea, albumin, AST, GGT, NEFA and phosphorus), body weight gain, testicular weight, interest time for artificial sow, sperm characteristics (volume, motility, vigor, concentration, spermatic pathologies, acrosomal and plasma membrane integrity and mitochondrial function), and seminal plasma constituents (fructose, cholesterol, total protein and IGF-I) with a Tukey test adjustment. Semen analyses and seminal plasma constituents were grouped every two weeks. The number of attempts needed for first mount and number of attempts needed for first ejaculation were evaluated by one-way ANOVA. The libido score was evaluated by Chi-square test.

\section{RESULTS}

The pST group had increased body weight gain

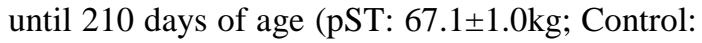
$64.2 \pm 1.0 \mathrm{~kg} ; \mathrm{P}=0.07)$. After 210 days of age, body weight was not different between groups (pST: $115.4 \pm 2.5 \mathrm{~kg}$; Control: $110.3 \pm 2.5 \mathrm{~kg}$; $\mathrm{P}>0.05)$. In addition, the pST group had higher testicular weight than Control group $(\mathrm{P}<0.001)$, with significant differences only observed at 365 days of age (Figure 1).

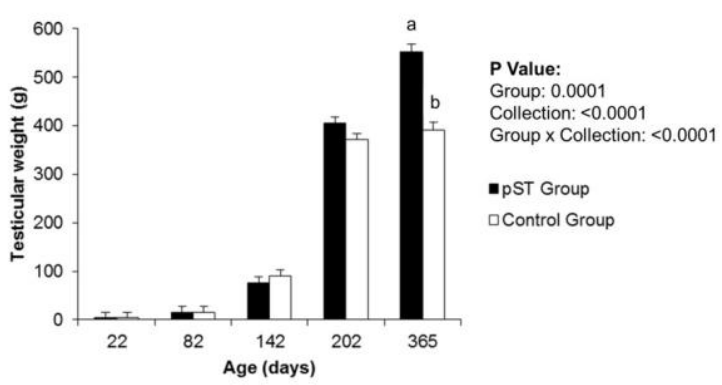

Figure 1. Testicular weight (mean \pm standard error of mean) of the young pigs submitted to somatotropin (pST) injection from 22 to 330 days of age.

pST Group ( $n=30)$ : treated with pST every three days up to 330 days of age; Control Group $(n=30)$ : received placebo treatment at the same frequency; Collection: time of orchiectomy; Group x Collection: analyze the interaction between group and collection.

${ }^{\mathrm{a}, \mathrm{b}} \mathrm{P}<0.05$.

Testosterone concentration was higher in the pST group, being higher from 181 to 239 days of age in pST treated pigs (Figure 2). Serum IGF-I concentration was not different between groups throughout the period of study (pST: $15.4 \pm 2.4 \mathrm{ng} / \mathrm{mL} ; \quad$ Control: $\quad 13.0 \pm 2.4 \mathrm{ng} / \mathrm{mL}$; $\mathrm{P}>0.05)$. Regarding the metabolic parameters, until 210 days of age concentrations of albumin (pST: $3.5 \pm 0.1 \mathrm{~g} / \mathrm{dL} ; \quad$ Control: $3.3 \pm 0.1 \mathrm{~g} / \mathrm{dL})$, glucose $(\mathrm{pST}$ : $91.7 \pm 1.3 \mathrm{mg} / \mathrm{dL}$; Control: $90.2 \pm 1.2 \mathrm{mg} / \mathrm{dL})$, cholesterol (pST: $73.0 \pm 1.7 \mathrm{mg} / \mathrm{dL}$; Control: $74.1 \pm 2.1 \mathrm{mg} / \mathrm{dL}$ ), urea (pST: $30.8 \pm 0.7 \mathrm{mg} / \mathrm{dL}$; Control: $32.9 \pm 0.7 \mathrm{mg} / \mathrm{dL}$ ), AST (pST: $21.7 \pm 1.1 \mathrm{UI} / \mathrm{L} ; \quad$ Control: $21.9 \pm 1.0 \mathrm{UI} / \mathrm{L}$ ) and GGT (pST: $115.2 \pm 7.5 \mathrm{UI} / \mathrm{L}$; Control: $126.9 \pm 8.8 \mathrm{UI} / \mathrm{L})$ were not different between groups $(\mathrm{P}>0.05)$. With reference to metabolic parameters after 210 days of age, only serum albumin (pST: $4.0 \pm 0.1 \mathrm{~g} / \mathrm{dL}$; Control: $3.6 \pm 0.1 \mathrm{~g} / \mathrm{dL} ; \mathrm{P}<0.001)$ and phosphorus (pST: $7.5 \pm 0.1 \mathrm{mg} / \mathrm{dL}$; Control: $7.0 \pm 0.1 \mathrm{mg} / \mathrm{dL} ; \mathrm{P}=0.06$ ) were higher in the pST than Control group. Glucose (pST: $74.9 \pm 1.4 \mathrm{mg} / \mathrm{dL}$; Control: $74.4 \pm 1.4 \mathrm{mg} / \mathrm{dL}$ ), cholesterol (pST: $77.5 \pm 2.0 \mathrm{mg} / \mathrm{dL}$; Control: $74.5 \pm 2.0 \mathrm{mg} / \mathrm{dL}$ ), urea (pST: $30.1 \pm 1.2 \mathrm{mg} / \mathrm{dL}$; Control: $29.5 \pm 1.2 \mathrm{mg} / \mathrm{dL}$ ), AST (pST: $24.2 \pm 1.5 \mathrm{UI} / \mathrm{L} ; \quad$ Control: 26.8 $\pm 1.5 \mathrm{UI} / \mathrm{L}$ ) and GGT (pST: 95.7 $\pm 14.0 \mathrm{UI} / \mathrm{L}$; Control: $87.6 \pm 14.0 \mathrm{UI} / \mathrm{L}$ ) concentrations were also not different between groups after 210 days of age $(\mathrm{P}>0.05)$. 


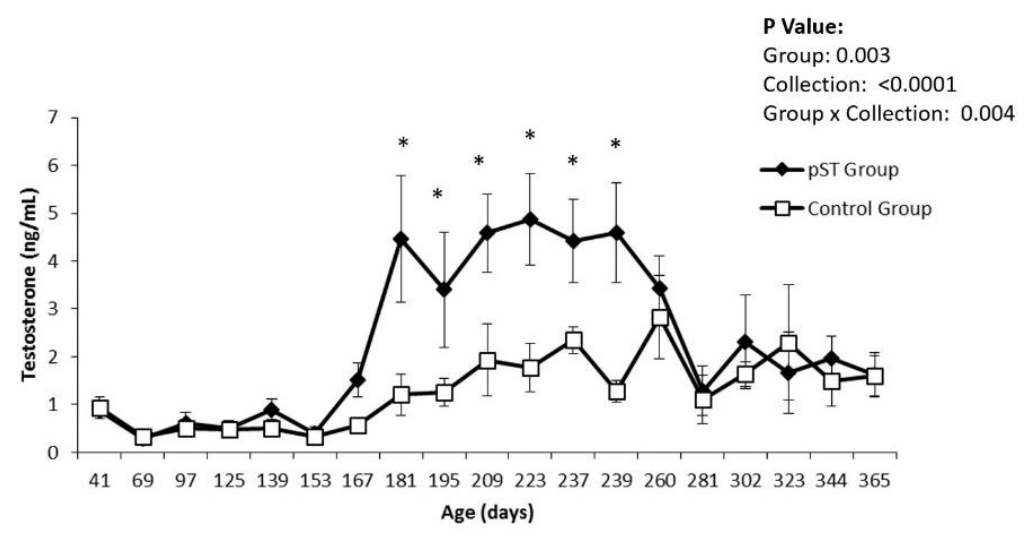

Figure 2. Testosterone concentration ( $\mathrm{ng} / \mathrm{mL}$; mean \pm standard error of the mean) of male pigs submitted to administration of porcine somatotropin (pST) from 22 to 330 days of age and submitted to orchiectomy at 365 days of age.

pST Group (n=6): treated with pST every three days up to 330 days of age; Control Group $(n=6)$ : received placebo treatment at the same frequency; Collection: blood collection used to determination of testosterone levels; Group $\mathrm{x}$ Collection: analyze the interaction between group and collection.

* Groups $\mathrm{P}<0.05$.

Regarding the reproductive behavior, pST treated boars had a greater number of mounts with semen collection compared to the Control boars $(\mathrm{P}<0.01)$ (Figure 3). Average time of interest in the artificial sow was higher for pST treated boars $(87.9 \pm 6.4 \mathrm{sec})$ than that for Control ones $(63.0 \pm 3.9 \mathrm{sec}) \quad(\mathrm{P}<0.001)$. The number of

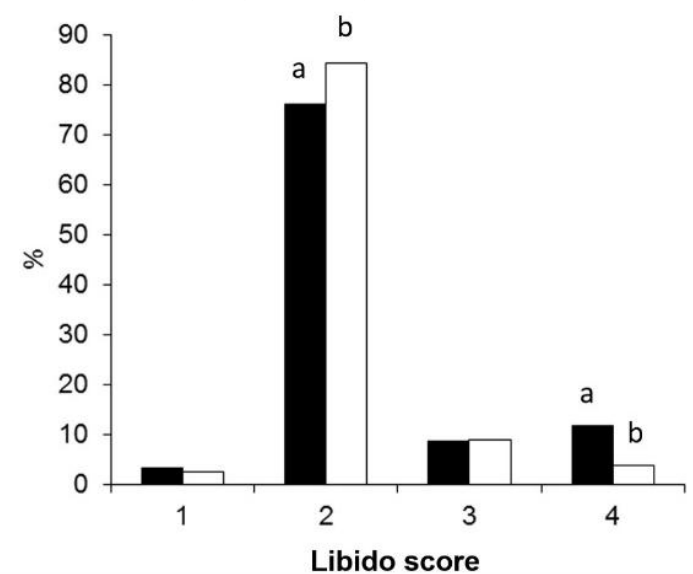

Figure 3. Effect of porcine somatotropin (pST) on libido score of the young boars from 150 to 210 days of age. Libido score: 1 - boars showed no interest in the artificial sow; 2 - slight interest in the artificial sow but did not attempt to mount; 3 - mounted the artificial sow but did not allow semen collection; 4 mounted the artificial sow and allowed semen collection.

pST Group ( $n=12)$ : treated with pST every three days up to 330 days of age; Control Group $(n=12)$ : received placebo treatment at the same frequency.

pST group libido score (\%): $1=3.25 ; 2=76.22 ; 3=8.79 ; 4=11.72$.

Control group libido score $(\%): 1=2.57 ; 2=84.56 ; 3=9.00 ; 4=3.85$.

${ }^{\mathrm{a}, \mathrm{b}} \mathrm{P}<0.05$.

Arq. Bras. Med. Vet. Zootec., v.70, n.1, p.73-81, 2018 attempts needed for the first mount was $6.3 \pm 1.4$ for the pST group and $6.2 \pm 1.0$ for the Control group $(\mathrm{P}>0.05)$, and the number of attempts needed for first ejaculation was $7.9 \pm 0.8$ for the pST Group and 6.4 \pm 1.3 for the Control Group $(\mathrm{P}>0.05)$.

\section{$P$ Value \\ a,b $P<0.05$ \\ -pST Group \\ $\square$ Control Group}


Seminal plasma IGF-I concentrations were higher for the pST group (pST: $99.4 \pm 4.7 \mathrm{ng} / \mathrm{mL}$; Control: $82.7 \pm 7.2 \mathrm{ng} / \mathrm{mL} ; \mathrm{P}=0.05)$, although no treatment by collection interaction was observed $(\mathrm{P}>0.05)$. Other biochemical constituents of the seminal plasma were not different between groups: total protein $(\mathrm{pST}$ : $3.4 \pm 0.6 \mathrm{~g} / \mathrm{dL}$; Control: $3.4 \pm 1.0 \mathrm{~g} / \mathrm{dL} ; \quad \mathrm{P}>0.05)$, cholesterol $\quad(\mathrm{pST}$ : $8.8 \pm 1.5 \mathrm{mg} / \mathrm{dL}$; Control: $11.5 \pm 2.4 \mathrm{mg} / \mathrm{dL} ; \mathrm{P}>0.05)$ and fructose $(\mathrm{pST}$ : $5.8 \pm 1.2 \mathrm{mg} / \mathrm{mL}$; Control: $6.5 \pm 1.8 \mathrm{mg} / \mathrm{mL} ; \mathrm{P}>0.05)$.

Regarding semen characteristics sperm motility

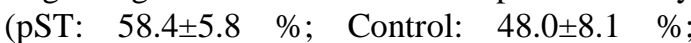
$\mathrm{P}>0.05$ ), vigor (pST: $2.1 \pm 0.2$; Control: $2.0 \pm 0.3$; $\mathrm{P}>0.05)$ and volume (pST: $25.6 \pm 9.6 \mathrm{~mL}$; Control: $10.5 \pm 12.6 \mathrm{~mL} ; \quad \mathrm{P}>0.05)$ were not different between groups in the period from 150 to 210 days of age. Nevertheless, fresh and stored semen characteristics were improved by $\mathrm{pST}$ treatment after 210 days of age. Sperm vigor was higher for fresh semen in the pST Group (Table 1), but no effect during storage was observed (Table 2). pST treatment had no effect on fresh semen motility (Table 1); however, when semen was stored for 72 hours, lower motility was observed in the Control group after 48 hours, while semen from the pST group presented stable motility during the 72-hour storage (Table 2). Additionally, during the 72hour storage sperm from the pST group had fewer morphological alterations and reduced plasma membrane damage $(\mathrm{P}=0.07)$ (Table 2). The pST group also presented lower sperm concentration, but a higher ejaculate volume and increased total sperm output. Due to this alteration, the pST group had a higher number of inseminating doses per ejaculate (Table 1).

Table 1. Fresh semen parameters (mean \pm standard error of mean) during the period from 210 to 365 days of age of boars receiving somatotropin (pST) injection from 22 to 330 days of age

\begin{tabular}{cccccc} 
Parameters & & & \multicolumn{3}{c}{ P Value } \\
\cline { 4 - 6 } & $\mathrm{pST}$ & Control & Group & Collection & $\begin{array}{c}\text { Group } \mathrm{x} \\
\text { Collection }\end{array}$ \\
\hline Ejaculate volume $(\mathrm{mL})$ & $174.5 \pm 18.7 \mathrm{a}$ & $40.1 \pm 11.8 \mathrm{~b}$ & $<0.001$ & 0.15 & 0.28 \\
Sperm motility $(\%)$ & $74.7 \pm 3.3$ & $67.5 \pm 3.6$ & 0.15 & 0.80 & 0.59 \\
Sperm vigor (score: $0-5)$ & $3.0 \pm 0.1 \mathrm{a}$ & $2.6 \pm 0.1 \mathrm{~b}$ & 0.02 & 0.45 & 0.32 \\
Sperm concentration $\left(\mathrm{x} 10^{6} / \mathrm{mL}\right)$ & $346.5 \pm 39.9 \mathrm{a}$ & $608.4 \pm 69.6 \mathrm{~b}$ & 0.001 & 0.07 & 0.34 \\
Sperm output $\left(\mathrm{x} 10^{9} /\right.$ ejaculate) & $63.1 \pm 11.2 \mathrm{a}$ & $22.3 \pm 9.3 \mathrm{~b}$ & 0.047 & 0.11 & 0.10 \\
Number of semen doses & $20.9 \pm 3.7 \mathrm{a}$ & $7.4 \pm 3.1 \mathrm{~b}$ & 0.047 & 0.11 & 0.10 \\
(3x10 sperm/dose) & $7.6 \pm 0.1$ & $7.5 \pm 0.1$ & 0.58 & 0.21 & 0.11 \\
pH & &
\end{tabular}

${ }^{\mathrm{a}, \mathrm{b}}$ Different superscripts within the same row indicate significant differences $(\mathrm{P}<0.05)$.

Table 2. Semen quality during $72 \mathrm{hs}$ of storage at $15^{\circ} \mathrm{C}$ (mean \pm standard error of mean) during the period from 210 to 365 days of age of boars receiving somatotropin (pST) injection from 22 to 330 days of age

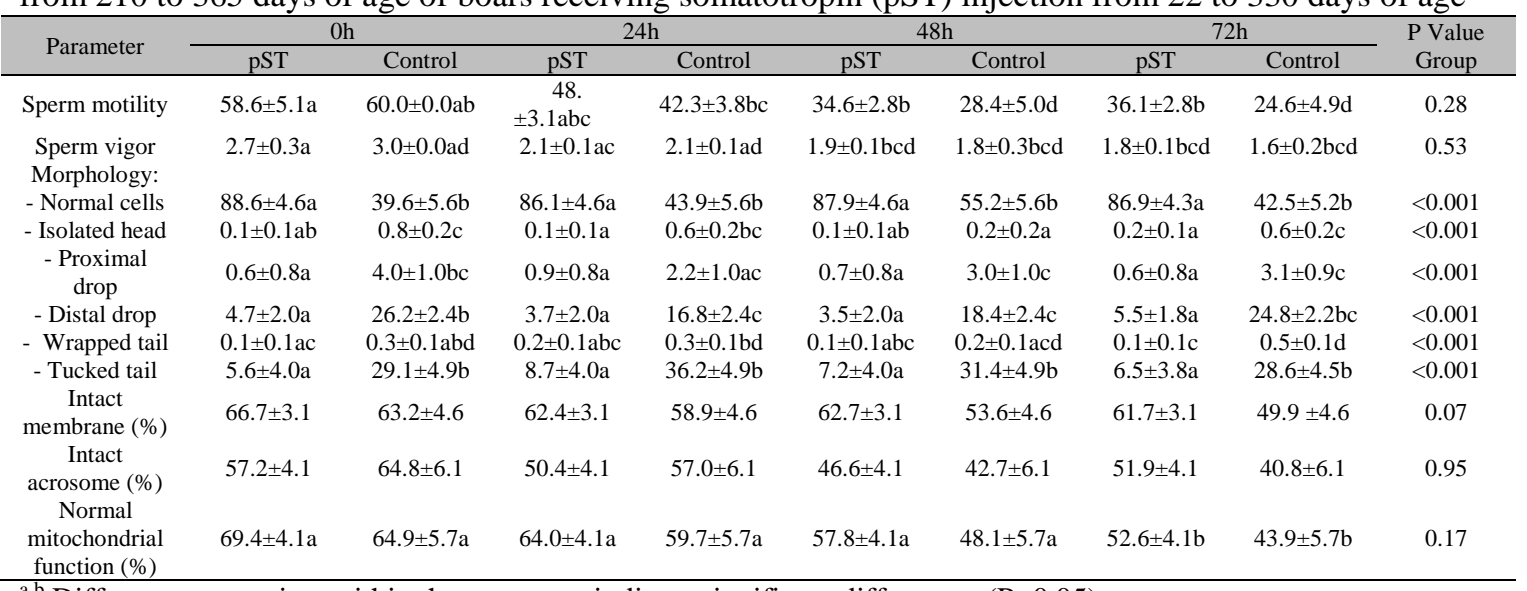

${ }^{\mathrm{a}, \mathrm{b}}$ Different superscripts within the same row indicate significant differences $(\mathrm{P}<0.05)$. 


\section{Effect of porcine...}

\section{DISCUSSION}

The current work has demonstrated that $\mathrm{GH}$ plays a pivotal role in the steroidogenesis and spermatogenesis of boars, as previously reported for other species in literature (Hafez et al., 2005; Storer et al., 2005; Vieira et al., 2010). Testicular steroidogenic activity is influenced by physiological development and endocrine status, and is associated to sexual maturity (Park and Yi, 2002). Based on the serum testosterone concentration, the present study suggests that sexual maturity occurred at an earlier age in pST treated boars, as indicated by the time of the first testosterone peak (Kumaresan et al., 2011). This earlier onset of sexual maturity is further supported by the sexual behavior of boars, since pST treated boars showed more interest in the artificial sow and mounts with ejaculation also at an earlier age. The effect of pST on testosterone concentration can be the result of an increased expression of $\mathrm{LH}$ receptors in Leydig cells as previously reported (Chatelain et al., 1991). Furthermore, IGF-I can directly stimulate the expression of steroidogenic acute regulatory (StAR) protein and increase steroidogenesis in the testis (Yoon and Roser, 2011).

pST treatment had no effect on semen quality of boars from 150 to 210 days old. Nonetheless, ElGohary et al. (2011) observed increased sperm motility and ejaculate volume in rams treated with rbST around the establishment of puberty. In addition, pST had no effect on testicular size during this period in our study. Nevertheless, pST treatment increased testicular size after puberty establishment, corroborating with the improved semen parameters observed in the post-pubertal period. Several studies indicate that testis size is positively correlated with sperm count per ejaculate (Borg et al., 1993). This is in agreement with our current findings, since pST treatment concomitantly increased testicular weight, semen volume, total sperm count and number of semen doses per ejaculate. Our observations are also in agreement with findings from Hafez et al. (2005), who observed increased ejaculate volume, mass motility, total number of spermatozoa and a decreased percentage of abnormal sperm cells for bulls treated with rbST. No differences in testosterone concentration after puberty were observed by Hafez et al. (2005), so it is believed that pST did not improve sperm quality by this pathway. The
pST effect on spermatogenesis is probably due to an increased local production of IGF-I, which is significantly correlated with the percentage of morphologically normal spermatozoa and sperm motility (Glander et al., 1996). Therefore, improved semen quality of boars in our study can be attributed to the increased levels of IGF-I in the seminal plasma of pST treated boars. Sertoli, Leydig and peritubular cells secrete IGF-I, which stimulates DNA synthesis in spermatogenic cells and cell proliferation (Söder et al., 1992), increasing the number of spermatic cells in the ejaculate. Still, the improvement of sperm motility is attributed to increased energy metabolism (Selvaraju et al., 2009). However, mitochondrial function in spermatozoa and energetic parameters in seminal plasma did not vary in our study. The positive pST effect on motility is probably due to direct actions of $\mathrm{GH}$ or IGF-I in the spermatozoa (Henricks et al., 1998).

IGF-I has another important role as a seminal plasma antioxidant (Selvaraju et al., 2009), protecting spermatozoa against damage in the plasmatic membrane during storage. During cold storage of boar semen between 17 and $19^{\circ} \mathrm{C}$, the sperm cell ability to resist the refrigeration process is impaired by its inability to adjust membrane fluidity, which in turn is related to integrity and changes in the lipid composition of the plasma membrane (Cerolini et al., 2000). As demonstrated in this study, pST treatment increased the proportion of spermatozoa with intact membranes, which is probably due to the protective IGF-I effect on the sperm membrane, previously reported in bulls (Vieira et al., 2010). As a result, sperm motility decreased less in pST treated boars at 48 hours of storage, which contributed to increased semen quality during conservation. pST treated boars also had lower sperm defects, which can be explained by the effect of IGF-I on spermatozoa maturation, decreasing the concentration of abnormal cells, as reported before (Glander et al., 1996). Additionally, the previous reports of IGF-I effects on the sperm membrane integrity can lead to reduced rates of sperm defects.

In the current study, $\mathrm{GH}$ also influenced protein and mineral metabolism. The effect of pST on albumin concentration is attributed to its influence on liver protein turnover, as demonstrated by the decrease in albumin levels 
in hypophysectomised rats and its partial restoration after GH supplementation (Feldhoff et al., 1977). The increase in phosphorus concentration can be explained by the antiphosphaturic effect of GH mediated by IGFI, which increases renal phosphorus reabsorption (Kopple et al., 1995). This effect can contribute to $\mathrm{GH}$ influence on energy metabolism, through the retention of phosphorus for ATP production, and which could be related to an increased sperm motility during storage (Lamirande and Gagnon, 1992). pST administration did not improve IGF-I blood concentrations in this study, differing from the results found by Samaras et al. (1994), suggesting that the pST effect on spermatogenesis and steroidogenesis can be mediated by an increase in local IGF-I production in this study, and be independent of endocrine effects.

\section{CONCLUSIONS}

The pST treatment of young boars increased the testosterone concentration and libido, and had a positive effect on metabolic balance. In the testicles, pST treatment increased the testicular weight and sperm quality of both fresh (vigor, volume, and total sperm concentration) and stored semen (motility, number of morphological alterations and integrity of plasmatic membrane).

\section{ACKNOWLEDGEMENTS}

This work was supported by CNPq (grant $\mathrm{n}^{\circ} 478385 / 2009-9$ ) and FAPERGS (grant $\left.\mathrm{n}^{\circ} 0904231\right)$.

\section{REFERENCES}

BAGU, E.T.; COOK, S.; GRATTON, C.L. et al. Postnatal changes in testicular gonadotropin receptors, serum gonadotropin, and testosterone concentrations and functional development of the testes in bulls. Reproduction, v.132, p.403-411, 2006.

BORG, K.E.; LUNSTRA，D.D.; CHRISTENSON, R.K. Semen characteristics, testicular size, and reproductive hormone concentrations in mature Duroc, Meishan, Fengjing, and Minzhu boars. Biol. Reprod., v.49, p.515-521, 1993.

BRITO, L.F.C.; BARTH, A.D.; RAWLINGS, N.C. et $a l$. Effect of nutrition during calfhood and peripubertal period on serum metabolic hormones, gonadotropins and testosterone concentrations, and on sexual development in bulls. Domest. Anim. Endocrinol., v.33, p.1-18, 2007.
CEROLINI, S.; ARRUDA, R.P.; DE ANDRADE, A.F.C. et al. Viability, susceptibility to peroxidation and fatty acid composition of boar semen during liquid storage. Anim. Reprod. Sci., v.58, p.99-111, 2000.

CHATELAIN, P.G.; SANCHEZ, P.; SAEZ, J.M. Growth hormone and insulin-like growth factor i treatment increase testicular luteinizing hormone receptors and steroidogenic responsiveness of growth hormone deficient dwarf mice. Endocrinology, v.128, p.1857-1862, 1991.

EL-GOHARY, E.S.; ABDEL-KHALEK, E.A.; ASHMAWY, T.A.M. et al. Effect of recombinant bovine somatotropin (rbST) on growth performance and puberty incidence of male and female lambs born from rbST treated ewes. Egypt. J. Sheep Goat Sci., v.6, p.47-55, 2011

FELDHOFF, R.C.; TAYLOR, J.M.; JEFFERSON, L.S. Synthesis and secretion of rat albumin in vivo, in perfused liver, and in isolated hepatocytes - effects of hypophysectomy and growth hormone treatment. $J$. Biol. Chem., v.252, p.3611-3616, 1977.

FINNERTY, M.; ENRIGHT, W.J.; ROCHE, J.F. Testosterone, LH and FSH episodic secretory patterns in GnRH-immunized bulls. J. Reprod. Fertil., v.114, p.85-94, 1998

FOLCH, J.; RAMON, J.P.; COCERO, M.J. et al. Exogenous growth hormone improves the number of transferable embryos in superovulated ewes. Theriogenology, v.55, p.777-785, 2001

FRASER, L.; LECEWICZ, M.; STRZEŻEK, J. Fluorometric assessments of viability and mitochondrial status of boar spermatozoa following liquid storage. Pol. J. Vet. Sci., v.5, p.85-92, 2002.

GLANDER, H.J.; KRATZSCH, J.; WEISBRICH, C. et al. Insulin-like growth factor-I and $\alpha_{2}-$ macroglobulin in seminal plasma correlate with semen quality. Hum. Reprod., v.11, p.2454-2460, 1996.

HAFEZ, Y.M.; FAWZY, S.A.; EL-HENAWY, M.A. et al. Effect of recombinant bovine somatotropin $(\mathrm{rbST})$ on semen physical characteristics and some biochemical constituents in seminal plasma of Friesian bulls. Egypt. J. Anim. Prod., v.42, p.87-94, 2005.

HARRISON, R.A.P.; VICKERS, S.E. Use of fluorescent probes to assess membrane integrity in mammalian spermatozoa. J. Reprod. Fertil., v.88, p.343-352, 1990.

HENRICKS, D.M.; KOUBA, A.J.; LACKEY, B.R. et al. Identification of insulin-like growth factor-I in bovine seminal plasma and its receptor on spermatozoa: influence on sperm motility. Biol. Reprod., v.59, p.330-337, 1998. 
KAMP, G.A.; WAELKENS, J.J.J.; DE MUINCK KEIZER-SCHRAMA, S.M.P.F. et al. High dose growth hormone treatment induces acceleration of skeletal maturation and an earlier onset of puberty in children with idiopathic short stature. Arch. Dis. Child., v.87, p.215-220, 2002.

KOPPLE, J.D.; DING, H.; HIRSCHBERG, R. Effects of recombinant human insulin-like growth factor 1 on renal handling of phosphorus, calcium, and sodium in normal humans. Am. J. Kidney Dis., v.26, p.818-824, 1995.

KOZINK, D.M.; ESTIENNE, M.J.; HARPER, A.F. et al. The effect of lutalyse on the training of sexually inexperienced boars for semen collection. Theriogenology, v.58, p.1039-1045, 2002.

KUMARESAN, A.; BUJARBARUAH, K.M.; KADIRVEL, G. et al. Early sexual maturity in local boars of Northeastern India: age-related changes in testicular growth, epididymal sperm characteristics and peripheral testosterone levels. Theriogenology, v.75, p.687-695, 2011

LAMIRANDE, E.; GAGNON, C. Reactive oxygen species and human spermatozoa. II. Depletion of adenosine triphosphate plays an important role in the inhibition of sperm motility. J. Androl., v.13, p.379386, 1992.

PARK, C.S.; YI, Y.J. Comparison of semen characteristics, sperm freezability and testosterone concentration between Duroc and Yorkshire boars during seasons. Anim. Reprod. Sci., v.73, p.53-61, 2002.

RABASSA, V.R.; SCHWEGLER, E.; SCHNEIDER, A. et al. Effect of porcine somatotropin on metabolism and testicular characteristics of prepubertal pigs. Braz. J. Vet. Res. Anim. Sci., v.51, p.60-67, 2014.

SAMARAS, S.E.; HAGEN, D.R.; BRYAN, K.A. et al. Effects of growth hormone and gonadotropin on the insulin-like growth factor system in the porcine ovary. Biol. Reprod., v.50, p.178-186, 1994.
SELVARAJU, S.; REDDY, I.J.; NANDI, S. et al. Influence of IGF-I on buffalo (Bubalus bubalis) spermatozoa motility, membrane integrity, lipid peroxidation and fructose uptake in vitro. Anim. Reprod. Sci., v.113, p.60-70, 2009.

SIROTKIN, A.V. Control of reproductive processes by growth hormone: extra- and intracellular mechanisms. Vet. J., v.170, p.307-317, 2005.

SJOGREN, I.; JONSSON, M.; MADEJ, A. et al. Effects of very high doses of human growth hormone (hGH) on the male reproductive system in the dog. Andrologia, v.30, p.37-42, 1998.

SÖDER, L.; BANG, P.; WAHAB, A. et al. Insulinlike growth factors selectively stimulate spermatogonial, but not meiotic, deoxyribonucleicacid synthesis during rat spermatogenesis. Endocrinology, v.131, p.2344-2350, 1992.

STORER, W.A.; THOMPSON JR, D.L.; CARTMILL, J.A. The effects of equine somatotropin on pituitary and testicular function in the stallion during the nonbreeding season. J. Equine Vet. Sci., v.25, p.106-112, 2005.

SWANLUND, D.J.; N'DIAYE, M.R.; LOSETH, K.J. et al. Diverse testicular responses to exogenous growth hormone and follicle-stimulating hormone in prepubertal boars. Biol. Reprod., v.53, p.749-757, 1995.

VIEIRA, M.B.; BIANCHI, I.; MADEIRA, E.M. et al. Effect of recombinant bovine somatotropin on plasma concentrations of insulin-like growth factor I, insulin and membrane integrity of bull spermatozoa. Reprod. Domest. Anim., v.45, p.1110-1113, 2010.

YOON, M.J.; ROSER, J.F. A synergistic effect of insulin-like growth factor (IGFI) on equine luteinizing hormone $(\mathrm{eLH})$-induced testosterone production from cultured Leydig cells of horses. Anim. Reprod. Sci., v.126, p.195-199, 2011. 